\title{
Feeding aspects of Knodus heteresthes (Eigenmann, 1908) and Moenkhausia lepidura (Kner, 1858) (Characiformes, Characidae) in the Teles Pires and Juruena Rivers, southern Amazon
}

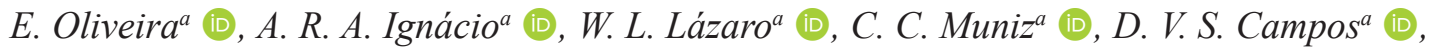 \\ J. V. M. Costa ${ }^{a}$ (D), T. Ribeiro ${ }^{a}$ (D) and M. Santos-Filho ${ }^{a *}$
}

${ }^{a}$ Centro de Pesquisa de Limnologia, Biodiversidade e Etnobiologia do Pantanal, Universidade do Estado de Mato Grosso - UNEMAT, Av. Santos Dumont, s/n, Cidade Universitária, CEP 78200-000, Cáceres, MT, Brasil

*e-mail: msantosfilho@gmail.com

Received: July 19, 2019 - Accepted: December 10, 2019 - Distributed: May 31, 2021

(With 4 figures)

\begin{abstract}
The composition of the diet of two species of characids (Knodus heteresthes and Moenkhausia lepidura) was evaluated in the Teles Pires and Juruena Rivers, sampled in September and October 2016. We analyzed 226 stomachs of $K$. heteresthes and 425 of M. lepidura. The analysis of the stomach contents was based on volumetric and frequency of occurrence methods, applying the food importance index. For the similarity of the diets between the species we calculated the niche overlap with Pianka's index. Both species in the Juruena River have a dietary preference for arthropods (IAi > 0.95). In the Teles Pires River the diet is concentrated in three sources for both species: arthropods (IAi > 0.52), vegetables (IAi > 0.33) and fish (IAi > 0.12). The diet was dissimilar when compared to environments (ANOSIM, $\mathrm{R} \geq 0.57, \mathrm{p}<0.001)$ with high trophic niche overlap $(\alpha>0.97$ ), regardless of the sampled environment. In the Teles Pires River, both species were classified as omnivorous with an insectivorous tendency and in the Juruena River the insectivorous behaviour occurs.
\end{abstract}

Keywords: diet, trophic niche, insectivory.

\section{Aspecto alimentar de Knodus heteresthes (Eigenmann, 1908) e Moenkhausia lepidura (Kner, 1858) (Characiformes, Characidae) nos rios Teles Pires e Juruena, sul da Amazônia}

\begin{abstract}
Resumo
Foram avaliadas a composição da dieta de duas espécies de Characideos (Knodus heteresthes e Moenkhausia lepidura) nos rios Teles Pires e Juruena, amostrados em setembro e outubro de 2016. Analisamos 226 estômagos de $K$. heteresthes e 425 de $M$. lepidura, sendo utilizados os métodos volumétrico e frequência de ocorrência, aplicando-se o índice de importância alimentar. Para a similaridade das dietas entre as espécies calculamos a sobreposição de nicho com índice de Pianka. Ambas as espécies no rio Juruena têm preferência alimentar por artrópodes (IAi $>0,95$ ), no rio Teles Pires a dieta concentra-se em três fontes para ambas espécies: artrópodes (IAi $>0,52)$, vegetais $($ IAi $>0,33)$ e peixes (IAi $>0,12)$. A dieta é dissimilar quando comparados os ambientes (ANOSIM, $R \geq 0,57 ; \mathrm{p}<0,001$ ), com alta sobreposição de nicho trófico $(\alpha>0,97)$, independente do ambiente amostrado. No rio Teles Pires, ambas as espécies foram classificadas como onívoras com tendência insetívora e no rio Juruena ocorre o comportamento insetívoro.
\end{abstract}

Palavras-chave: dieta, nicho trófico, insetivoria.

\section{Introduction}

Neotropical freshwater fish represent one-eighth of all vertebrate biodiversity and approximately one-fourth of that of the globe fish species (Vari and Malabarba, 1998), and among them, the Family Characidae (Characiformes) is the most diverse freshwater fish, with among 1600 described species (Lévêque et al., 2008), distributed along the South, Central and North America and Africa. Many species of Characidae, such as Knodus moenkhausii (Ceneviva-Bastos and Casatti, 2007), Bryconamericus microcephalus (Rezende and Mazzoni, 2003), Astyanax aff. bimaculatus and A. parahybae (Lopes et al., 2016) are generalists and/or opportunists in obtaining food resources.

Due to the huge diversity of species, morphological similarities and feeding habit, coexistence between some species of Characidae is still poorly understood in aquatic environments (Mol, 1995), while the segregation seems to 
play a significant role in modeling population dynamics (Ross, 1986). Although, Pianka (1974) points that two species can coexist only if they differ in at least one niche (trophic, spatial or temporal). Specziár and Erős (2014) suggest that the trophic segregation in aquatic environments can be more significant than habitat sharing or seasonality in the process of coexistence. In this perspective, studies focused on fish dietary can provide significant informations about community structure and habitat structure that can be useful in conservation programs (Barletta et al., 2010).

The generalist feeding habit can be reported as an strategy of coexistence (Pianka, 1974; Mazzoni et al., 2012). In Amazon region two species of Characidae, Knodus heteresthes (Eigenmann, 1908) and Moenkhausia lepidura (Kner, 1858), both generalist species, coexist along the streams (Costa et al., 2011; Casatti et al., 2013; Soares et al., 2014; Costa and Rocha, 2017), sharing the same resources. Thus, the objective of this study was to report the diet composition of two spatial coexisting species of Characidae, K. heteresthes (Eigenmann, 1908) and M. lepidura (Kner, 1858) in the Teles Pires and Juruena Rivers in order to determine changes in composition of the diet between the two great Amazonian rivers, as so, food preference, breadth and overlap of trophic niche between rivers.

\section{Material and Methods}

\subsection{Study area}

The Juruena and Teles Pires Rivers are important tributaries of the Tapajós basin and are located in the southern portion of the Brazilian Amazon (see Figure 1). They have a humid continental equatorial climate with a dry season (ICMBio, 2011) and a rainfall index of 2,500 mm (Molinier et al., 1996; ICMBio, 2011).

We collected samples in September and October 2016, respectively, in Teles Pires and Juruena. The Teles Pires River is approximately $1,370 \mathrm{~km}$ long and runs through important municipalities of Mato Grosso with agricultural and industrial activities involving soybean, corn, extraction of wood and gold, and livestock (Mato Grosso, 2004). The area is bordered by riparian forests of rural properties, and the presence of ranches on the islands is constant.

The Juruena River is about $1,080 \mathrm{~km}$ long, with a remarkable characteristic of several meanders along the course and a notorious complex of islands. The occupational use of the soil is marked by large areas dedicated to cattle raising, grain and sugarcane production and the timber industry (ICMBio, 2011). The collection area is bordered by riparian forest, with the presence of numerous islands with ciliary forest. At some points of the river, the same parallel has at least four islands.

\subsection{Sampling system}

Six sampling points were determined in each river, permeating the banks of the main riverbed and the banks of islands, with a maximum depth of $1.5 \mathrm{~m}$. The fish were collected by active method of fishing, with the aid of a $3 \mathrm{~mm}$ nylon mesh, assembled in a rectangular metal frame with dimensions of $100 \times 200 \mathrm{~cm}$ (picaré). The individuals collected were stored on ice in order to preserve the biological material. We recorded the biometrics (total length and standard length) of each specimen; the stomachs were removed and placed in $2 \mathrm{~mL}$ microtubes in $70 \%$ ethanol for preservation. The collections were carried out under SISBio license 24215 .

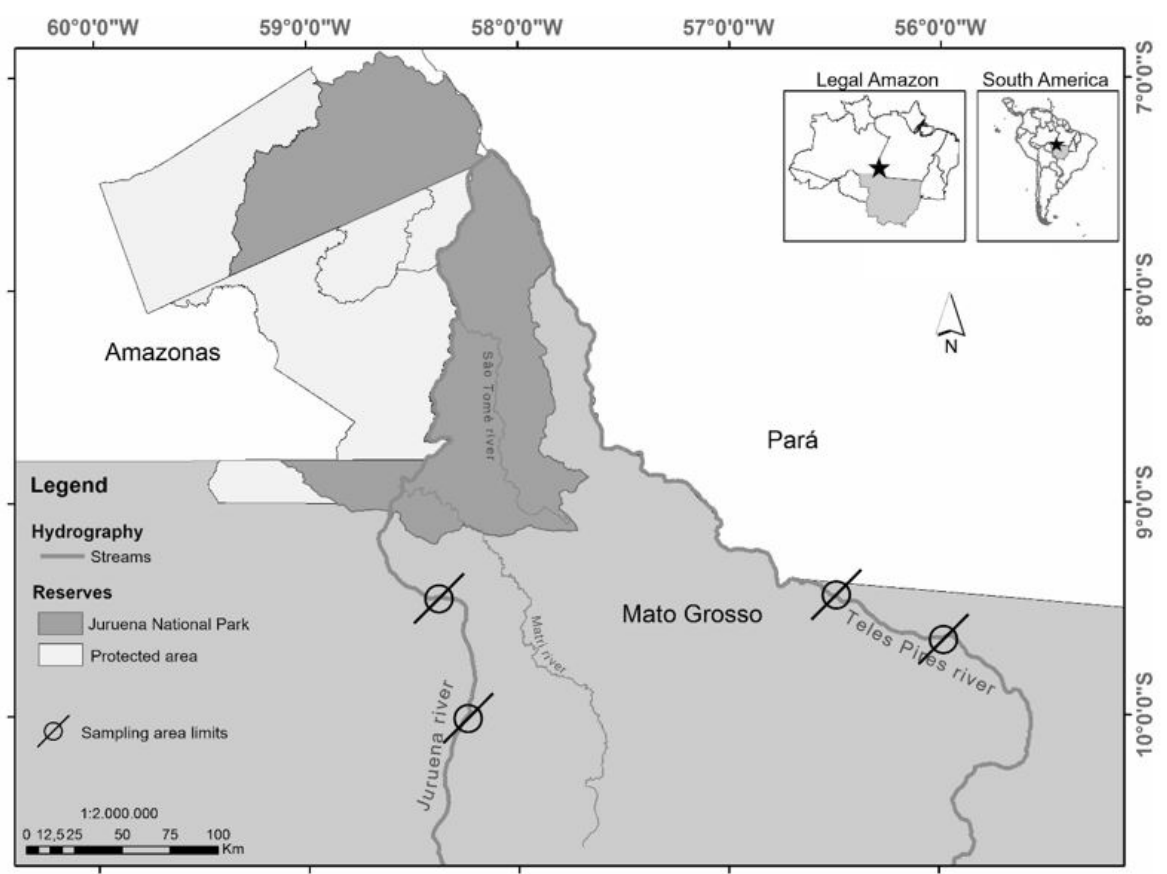

Figure 1. Juruena and Teles Pires Rivers, north of the state of Mato Grosso - Brazil, southern portion of the Amazon. 
Stomach contents were analyzed using a stereoscopic magnifying glass. The volume of the food items was obtained by means of a millimeter Petri dish (Hellawell and Abel, 1971). Food items were identified with the aid of identification guides (McCafferty, 1981; Roldán, 1988; Mugnai et al., 2010; Hamada et al., 2014).

\subsection{Data analysis}

For food analysis, the volumetric ( $\mathrm{Vi} \%)$ and relative occurrence frequency (Fi\%) methods (Hynes, 1950; Hyslop, 1980) and the Food Importance Index (IAi) (Kawakami and Vazzoler, 1980) were used, where IAi $=\mathrm{Fi} * \mathrm{Vi}) / \Sigma \mathrm{ni} \mathrm{Fi} * \mathrm{Vi}$ ), where $\mathrm{i}=$ food item, $\mathrm{F}=$ food item occurrence frequency (\%) and $\mathrm{V}=$ food item volume $\%$. The niche breadth was calculated using the Levins index (Hurlbert, 1978), where $\mathrm{B}=\left[\left(\sum \mathrm{jP} 2 \mathrm{ij}\right)-1-1\right](\mathrm{n}-1)-1$ where $\mathrm{B}=$ measurement of the niche breadth ( 0 to 1 ), $\mathrm{Pij}=$ proportion of the food item " $\mathrm{j}$ " in the diet of the " $\mathrm{i}$ " species, $\mathrm{n}=$ total food items. Values $<0.4$ are considered low (Novakowski et al., 2008). For the analysis of trophic niche overlap, we used the symmetric Pianka index (Pianka, 1973), with the model $\alpha=\Sigma(\mathrm{Pij} * \mathrm{Pik}) / \sqrt{ }\left(\Sigma \mathrm{Pij}^{2} * \Sigma \mathrm{Pik}^{2}\right)$ where $\alpha=$ niche overlap ( 0 to 1$), \mathrm{Pij}$ and $\mathrm{Pik}=$ proportion of item ' $\mathrm{i}$ ' used by species ' $\mathrm{j}$ ' and ' $\mathrm{k}$ '. The breadth and niche overlap analyzes were performed in software R, version 3.3.1.

Non-metric multidimensional scale analysis (NMDS) based on general IAi per point of collection was performed to ordinate the fish diet between the two rivers. The fishes were also grouped, arbitrary, in six size classes (A 2.5-2.9 cm; B 3-3.4 cm; C 3.5-3.9 cm; D 4-4.4 cm; E 4.5-4.9; F 5-5.4 cm). The dissimilarity matrix used in the ordering was constructed using the Bray-Curtis index. At the same time, the similarity analysis (ANOSIM) was carried out to verify the similarity significance between the sampled areas, using as a matrix the IAi of size classes and the IAi per collection point and specie, performed with the software Past ver. $2.17 \mathrm{c}$

Data of the IAi by all size classes and by point of collection were analyzed through. Principal Component Analysis (PCA) in order to evaluate a possible influence of food items in the composition of diet. For the composition of the analysis, we grouped the food items into six categories: invertebrates composed of insect, arachnida, zooplankton and nematode; fragment of arthropods; Ephemeroptera; Hymenoptera; fish; and plants. The indeterminate items and sand were not used in the analysis. PCA was performed with the Past ver. 2.17c.

\section{Results}

In total, 651 stomachs were analysed. Of these, 226 were of $K$. heteresthes and 425 of M. lepidura. One hundred individuals of $K$. heteresthes were collected in the Juruena River and 126 in the Teles Pires River, and for M. lepidura 177 were collected in the Juruena River and 248 in the Teles Pires River.

For M. lepidura of the Teles Pires River, 20 food items were registered and for $K$. heteresthes, 23. For the
Juruena River, 23 food items were found for $K$. heteresthes and 19 for $M$. lepidura. The total invertebrates found in the stomachs of $M$. lepidura and $K$. heteresthes from Teles Pires River represented IAi $=0.54$ and 0.52 , and for the Juruena River IAi $=0.95$ and 0.99 , respectively. The items of plant origin (plant fragment, seed, fruit and seaweed) in the Teles Pires River are the second most representative category, with $\mathrm{IAi}>0.33$ for both species in Teles Pires River, followed by items of animal origin (as show in Table 1). For the Juruena River, the items of plant origin presented IAi $<0.05$ (as show in Table 1) for both species.

When we added the relative volume of the food item (Vi\%) Hymenoptera and insect fragments, they represented, respectively, $\mathrm{Vi} \%=90.53$ and 77.69 of the diets of $K$. heteresthes and M. lepidura in the Juruena River, while in the Teles Pires River the values were $\mathrm{Vi} \% \approx 32$. For the Teles Pires River, the items of plant origin represented sums of $\mathrm{Vi} \%=41.51$ and 37.17 , and items derived from fish had values of $\mathrm{Vi} \%=16.24$ and 17.58 for $K$. heteresthes and M. lepidura, respectively (as show in Table 1).

The niche breadth was not higher than 0.217 in Teles Pires River and 0.097 in the Juruena River. The largest niche breadth in Teles Pires fish was associated with generalist behaviour and the omnivorous diet, including food items from different taxonomic categories such as arthropods, plants and fish. The lower breadth in the Juruena fish was associated with the insectivorous diet, with high consumption of insect fragments and Hymenoptera for both species, and consumption of several invertebrate taxonomic categories considered rare.

The niche overlap in both rivers was high, $\alpha=0.985$ in the Teles Pires River and $\alpha=0.971$ in the Juruena River (see Figure 2), indicating a possible sharing or competition of food resources at these sites.

The ordering produced by means of the NMDS showed evidence of the composition of the distinct food items in the rivers sampled, for both the size analysis of the IAi $($ Stress $=0.090)($ see Figure $3 \mathrm{~A})$ and the collection point (Stress $=0.099)$, considering the two species in the analysis (see Figure 3B). The dissimilar diet in both environments, considering the two species in the analysis, was also indicated by $\operatorname{ANOSIM}(\mathrm{R}=0.81, \mathrm{p}<0.001)$ for size class and $\operatorname{ANOSIM}(\mathrm{R}=0.57, \mathrm{p}<0.001)$ for collection points.

PCA of food items by size class revealed two major components (PC1 and PC2), which accounted for $97.21 \%$ of dietary variation (Figure 4A). The PC1 explained $73.41 \%$, strongly influenced by Hymenoptera, insect fragments and items of plant origin. For PCA of the items per collection point, the components $(\mathrm{PC} 1=53.57$; $\mathrm{PC} 2=32.45)$ were also influenced mainly by Hymenoptera, insect fragments and items of plant origin (see Figure 4B). In both PCAs, the greater presence of insect fragments and vegetal origin in the composition of the fish diet in the Teles Pires River is evident, and for the fish of the Juruena River, Hymenoptera and insect fragments were more prevalent. 
Table 1. Food items consumed by K. hetetresthes and M. lepidura in the Teles Pires and Juruena Rivers.

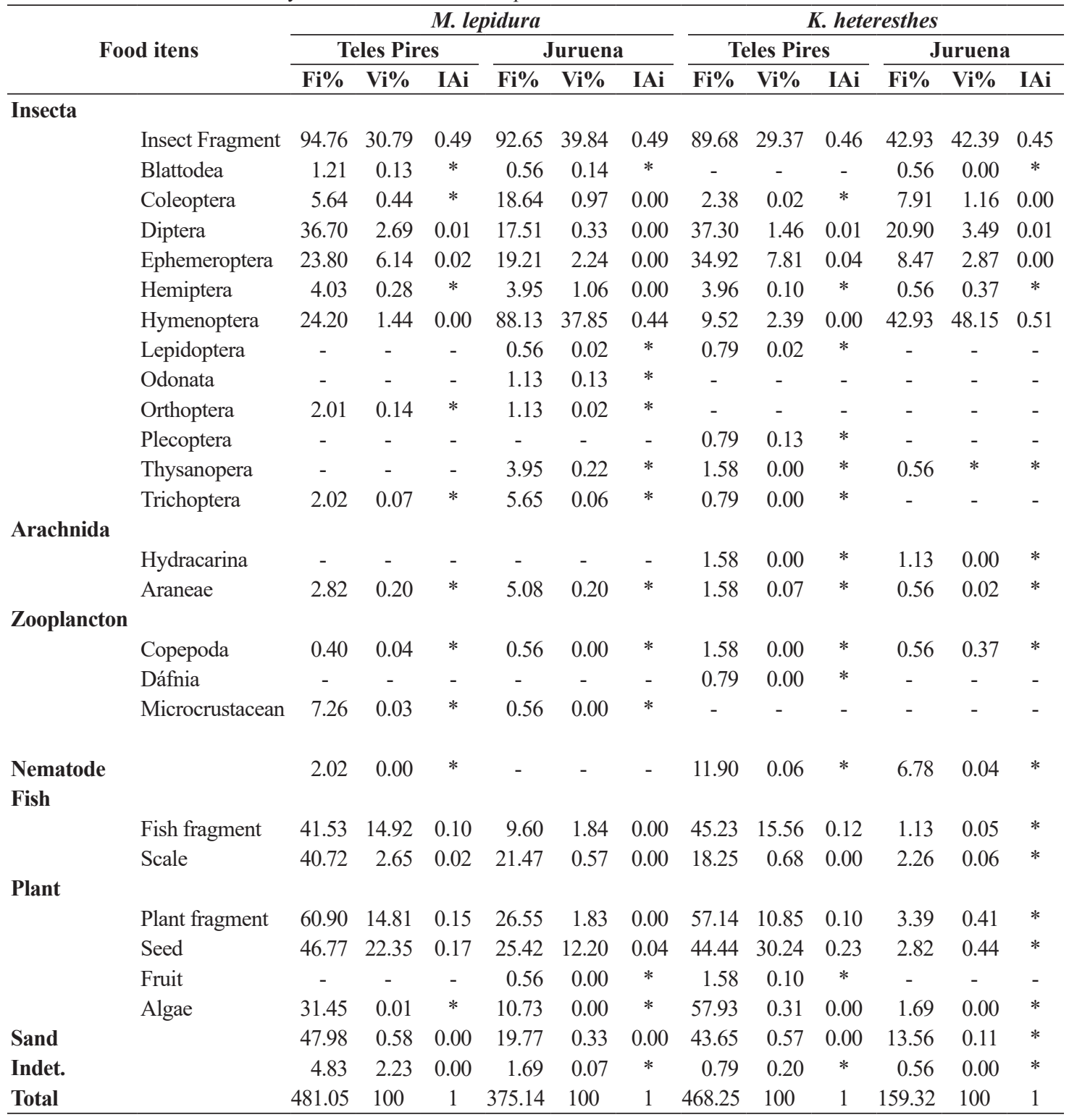

\section{Discussion}

The species $K$. heteresthes and M. lepidura had preference for high-protein food items, such as arthropods. This diet has been registered for several species of small fish, and in several studies these characids were classified as having an omnivorous diet with insectivorous tendency (Novakowski et al., 2008; Tófoli et al., 2010; Nogueira and Costa, 2014).

$K$. heteresthes is described as omnivorous in Amazonian environments (Nogueira and Costa, 2014) and the omnivore/insectivorous habit is described for other species of the genus, such as K. deuterodonoides and Knodus sp. on the Orinoco River in Venezuela (Ortaz et al., 2011). Moenkhausia lepidura is described as omnivorous with a high tendency towards invertivore (Sánchez et al.,
2003). Other species of the genus Moenkhausia, such as $M$. dichroura in reservoirs, have an omnivorous eating habit with an insectivorous tendency (Silva and Hahn, 2009). In the Pantanal, M. sanctaefilomenae is described as omnivorous with a herbivorous tendency (Santos et al., 2009). The omnivorous food habit was evidenced in our study for both species in the Teles Pires River, differing from the Juruena River, which was highly insectivorous. According to Schneider et al. (2011), the composition of the fish diet is variable, influenced by food availability and environmental characteristics. The latter, when analyzed by Ceneviva-Bastos and Casatti (2007) in streams of the Upper Paraná River, showed that the diet of Knodus moenkhausii in an environment of riparian forest differs from environments absent such forests, presenting high 


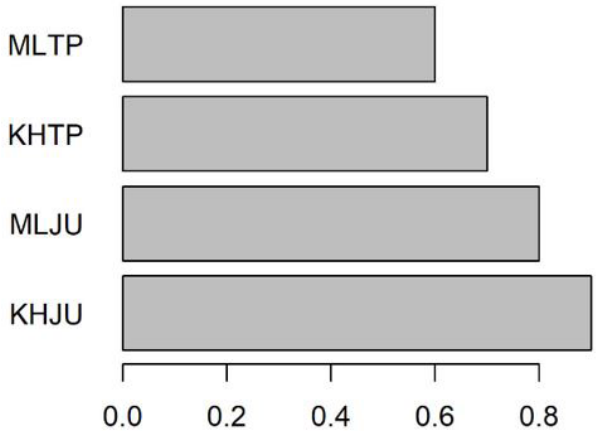

Niche breadth

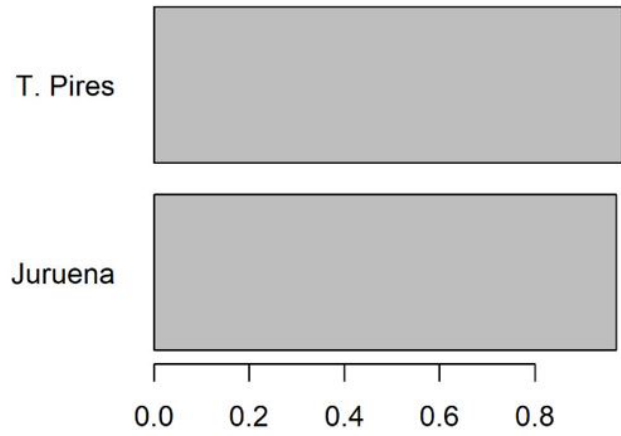

Niche overlap

Figure 2. Niche breadth and overlapping of $\mathrm{K}$. heterethes and $M$. lepidura in the Juruena and Teles Pires Rivers. $\mathrm{KHJU}=K$. heteresthes of the Juruena River; $\mathrm{MLJU}=M$. lepidura of the Juruena River; KHTP $=K$. heteresthes of the Teles Pires River; MLTP $=$ M. lepidura of the Teles Pires River.
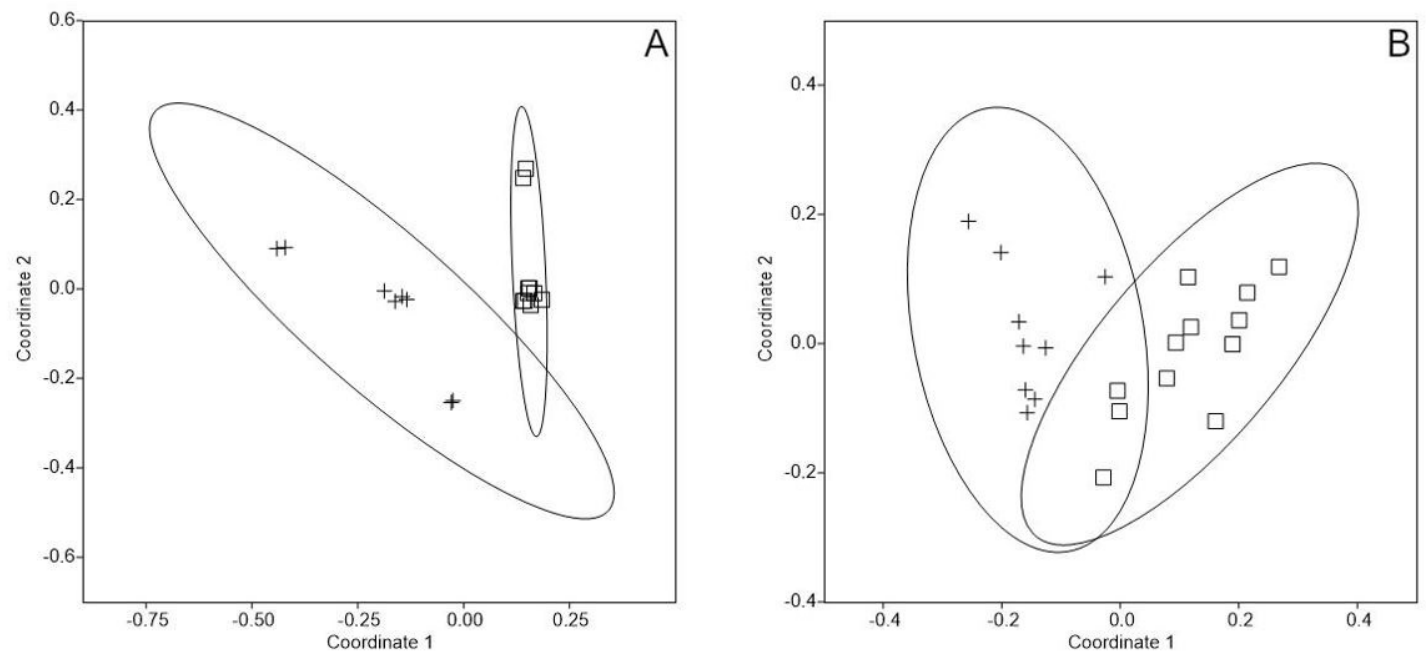

Figure 3. Biplot of the food items by size class (A) and between collection points (B) of K. heteresthes and M. lepidura in the the Teles Pires ( $\square$ ) and Juruena (+) Rivers.

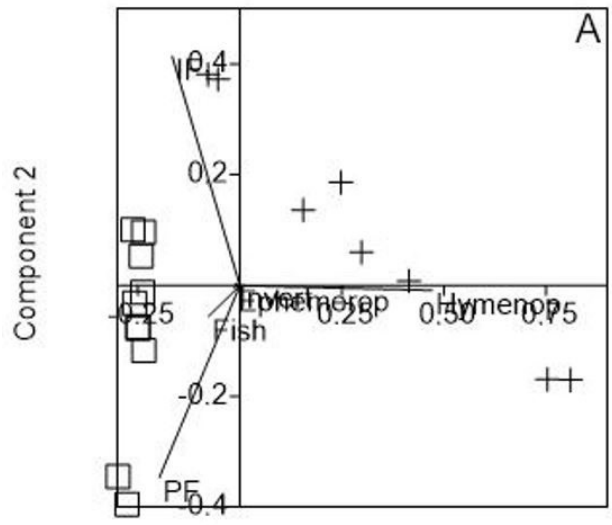

Component 1

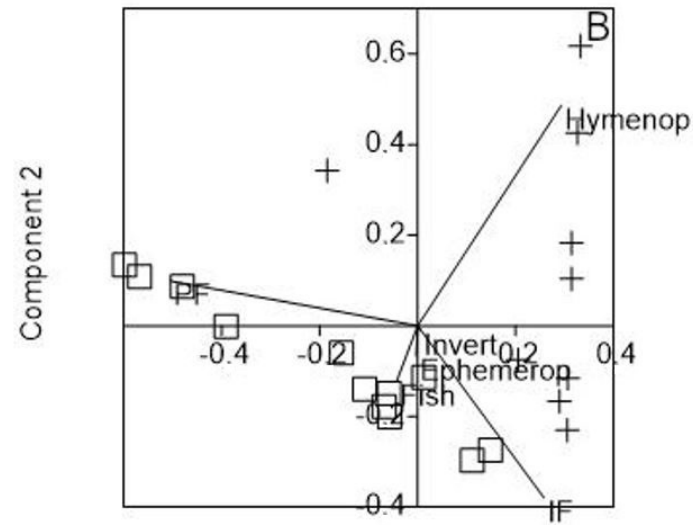

Component 1

Figure 4. PCA-based scatter plot of food items by size class (A) and collection point (B) of K. heteresthes and M. lepidura in the Teles Pires ( $\square$ ) and Juruena (+) rivers. Items: insect fragment (IF), Hymenoptera, Ephemeroptera, plant (PF), fish and other invertebrates (Invert). 
indexes of food items of allochthonous origin, such as invertebrates.

The Hymenoptera item of allochthonous origin in the Juruena River, with high values of $\mathrm{Fi} \%, \mathrm{Vi} \%$ and IAi, evidences the importance of maintaining the riparian forest preserved in the area, as well as the presence of protected areas close to the site, because, according to Lopes et al. (2016), environments with such conditions are essential for entry of food of allochthonous origin. This item was also expressive for $M$. dichroura and M. sanctaefilomenae in sympatric in the Alto Paraguay River basin, being in high abundance and availability because of the fall of the forest canopy from rain and wind (Tófoli et al., 2010). This predominance involves factors such as habitat diversity, marginal vegetation integrity and intensity and type of anthropic action applied to the environment (Ceneviva-Bastos and Casatti, 2007). In our study, we can associate these factors with the presence of several islands with well-preserved riparian vegetation in the Juruena River. Therefore, according to Schneider et al. (2011), the presence of marginal forests can contribute to the absence of seasonal variations in diets, as they act as barriers to contain environmental change and supply of resources.

The presence of recorded plant items for $K$. heteresthes and $M$. lepidura on the Teles Pires River is commonly observed for omnivorous Characiformes in other environments (Santos et al., 2009; Schneider et al., 2011; Costa and Rocha, 2017). These items seem to be a good nutritional alternative, because despite the low protein source, according to Fiori et al. (2016) these physiological adaptations allow the maximum attainment of energy from the food source. Alternatively, according to Bowen et al. (1995), the reduction of the energy rate can be compensated by the increase in consumption of these items. In this sense, we suggest that compensation can be attained through consumption of other foods of autochthonous origin, like fish, as found in our study: we found fragments of fish and scales with $\mathrm{Fi} \%>40 \%$ and $\mathrm{Vi} \%>16 \%$ and $\mathrm{IAi} \approx 0,12$. Scale of intake may be related to agnostic encounters (Vilella et al., 2002; Shibatta, 2006), or, alternatively, as an alternative source of calcium (Yasuaki et al., 1989).

The trophic niche breadth values were considered low $(\mathrm{B}<0.4)$ for both rivers sampled. When comparing the values of niche breadth, although low, the fish of the Teles Pires River presented twice the niche breadth when compared to the Juruena River. These results may be due to the greater diversification of food items consumed in the Teles Pires River. Our results converge to the values found for the omnivorous M. dichroura (Novakowski et al., 2008; Tófoli et al., 2010), Astyanax aff. bimaculatus and Astyanax parahybae (Lopes et al., 2016); the same occurs with the insectivorous Bryconamericus exodon (Novakowski et al., 2008). These low values are due to the generalist behavior evidenced, with high heterogeneity in the consumption of the items, especially for the several invertebrate taxa consumed with low frequency of occurrence. In addition, according to Abelha et al. (2001), in general, tropical fish behave like generalists.
The diet of both species in our study differs when compared to the two rivers sampled, but when compared in the same river, the species presented high trophic niche overlap. The item insect fragment, along with the identified insects, contributes strongly to the overlap found in our study. Feeding on insect exoskeleton fragments is an advantageous alternative, as exoskeletons are easily captured and maintain the nutritional value of whole insects with high protein value (Melo et al., 2004).

The values of the trophic niche overlap index $\alpha=0.9717$ (Juruena) and 0.9855 (Teles Pires) suggest that the food items partition is higher in both rivers. There was great availability of invertebrates in the Juruena River, with a tendency toward arthropod consumption specialization in the sampled period. In contrast, in the Teles Pires River, the higher contribution of items from three origins (arthropod, items of vegetal and animal origin such as fish) results in a low partition of food resources, which would cause interspecific competition. Factors such as period and foraging strategy (Casatti, 2002), trophic niche breadth, availability of resources and combination of microhabitats may allow the coexistence of species with high trophic niche overlap (Lopes et al., 2016).

\section{Conclusion}

$K$. heteresthes and M. lepidura present an omnivorous diet with insectivorous tendency in the Teles Pires River and insectivorous tendency in the Juruena River in the sampled period, evidencing the strong influence of habitat integrity and food availability on diet composition, as well as trophic plasticity. The high trophic niche overlap and low trophic niche breadth values allow us to infer that species coexistence in both environments can be minimized by food availability and by generalist behaviour in obtaining food.

\section{References}

ABELHA, M.C.F., AGOSTINHO, A.A. and GOULART, E., 2001. Plasticidade trófica em peixes de água doce. Acta Scientiarum, vol. 23, no. 2, pp. 425-434. http://dx.doi.org/10.4025/actascibiolsci. v23i0.2696.

BARLETTA, M., JAUREGUIZAR, A.J., BAIGUN, C., FONTOURA, N.F., AGOSTINHO, A.A., ALMEIDA-VAL, V.M.F., VAL, A.L., TORRES, R.A., JIMENES-SEGURA, L.F., GIARRIZZO, T., FABRÉ, N.N., BATISTA, V.S., LASSO, C., TAPHORN, D.C., COSTA, M.F., CHAVES, P.T., VIEIRA, J.P. and CORRÊA, M.F., 2010. Fish and aquatic habitat conservation in South America: a continental overview with emphasis on neotropical systems. Journal of Fish Biology, vol. 76, no. 9, pp. 2118-2176. http:// dx.doi.org/10.1111/j.1095-8649.2010.02684.x. PMid:20557657.

BOWEN, S.H., LUTZ, E.V. and AHLGREN, M.O., 1995. Dietary protein and energy as determinants of food quality: trophic strategies compared. Ecology, vol. 76, no. 3, pp. 899-907. http:// dx.doi.org/10.2307/1939355.

CASATTI, L., 2002. Alimentação dos peixes em um riacho do Parque Estadual Morro do Diabo, bacia do alto rio Paraná, sudeste do Brasil. Biota Neotropica, vol. 2, no. 2, pp. 1-14. http://dx.doi. org/10.1590/S1676-06032002000200012. 
CASATTI, L., PÉREZ-MAYORGA, M.A., CARVALHO, F.R., BREJÃO, G.L. and COSTA, I.D., 2013. The stream fish fauna from the rio Machado basin, Rondônia State, Brazil. Check List, vol. 9, no. 6, pp. 1496-1504. http://dx.doi.org/10.15560/9.6.1496.

CENEVIVA-BASTOS, M. and CASATTI, L., 2007. Oportunismo alimentar de Knodus moenkhausii (Teleostei, Characidae): uma espécie abundante em riachos do noroeste do Estado de São Paulo, Brasil. Iheringia: Série Zoologia, vol. 97, no. 1, pp. 7-15. http:// dx.doi.org/10.1590/S0073-47212007000100002.

COSTA, I., ROMAGNOLI, F., CARMO, T., RIBAS, C., GALDINO, R.L. and ZUANON, J., 2011. Ictiofauna associada a bancos de herbáceas aquáticas flutuantes na ilha da Marchantaria, rio Solimões, Amazônia Central, Brasil. Revista Colombiana de Ciencia Animal, vol. 3, no. 1, pp. 148-156. http://dx.doi. org/10.24188/recia.v3.n1.2011.352.

COSTA, I.D. and ROCHA, V.M., 2017. The influence of habitat structure on fish assemblages in Amazonian streams of Machado river basin. Revista de Biología Tropical, vol. 65, no. 1, pp. 103115. http://dx.doi.org/10.15517/rbt.v65i1.23287. PMid:29466632.

FIORI, L.F., ALVES, G.H.Z., HAHN, N.S. and BENEDITO, E., 2016. Influence of feeding plasticity on the fitness of small Neotropical characids. Iheringia: Série Zoologia, vol. 106, no. 0. http://dx.doi.org/10.1590/1678-4766e2016006.

HAMADA, N., NESSIMIAN, J.L. and QUERINO, R.B., 2014. Insetos aquáticos na Amazônia brasileira: taxonomia, biologia e ecologia. Manaus: Editora INPA, 724 p.

HELLAWELL, J.M. and ABEL, R., 1971. A rapid volumetric method for the analysis of the food of fishes. Journal of Fish Biology, vol. 3, no. 1, pp. 29-37. http://dx.doi.org/10.1111/j.1095-8649.1971. tb05903.x.

HURLBERT, S.H., 1978. The measurement of niche overlap and some relatives. Ecology, vol. 59, no. 1, pp. 67-77. http://dx.doi. org/10.2307/1936632.

HYNES, H.B.N., 1950. The food of fresh-water sticklebacks (Gasterosteus aculeatus and Pygosteus pungitius), with a review of methods used in studies of the food of fishes. Journal of Animal Ecology, vol. 19, no. 1, pp. 36-58. http://dx.doi.org/10.2307/1570.

HYSLOP, E.J., 1980. Stomach contents analysis: a review of methods and their application. Journal of Fish Biology, vol. 17, no. 4, pp. 411-429. http://dx.doi.org/10.1111/j.1095-8649.1980. tb02775.x.

INSTITUTO CHICO MENDES DE CONSERVAÇÃO DA BIODIVERSIDADE - ICMBio, 2011. Plano de manejo do Parque Nacional do Juruena. Brasília: ICMBio, 283 p.

KAWAKAMI, E. and VAZZOLER, G., 1980. Método gráfico e estimativa de índice alimentar aplicado no estudo de alimentação de peixes. Boletim do Instituto Oceanográfico, vol. 29, no. 2, pp. 205-207. http://dx.doi.org/10.1590/S0373-55241980000200043.

LÉVÊQUE, C., OBERDORFF, T., PAUGY, D., STIASSNY, M.L.J. and TEDESCO, P.A., 2008. Global diversity of fish (Pisces) in freshwater. Hydrobiologia, vol. 595, no. 1, pp. 545-567. http:// dx.doi.org/10.1007/s10750-007-9034-0.

LOPES, V.G., NESSIMIAN, J.L., DA-SILVA, E.R., GOMES, J.H.C., DIAS, A.C.I., SOUZA, L.C. and BRANCO, C.W., 2016. Habitat heterogeneity on feeding habit of two sympatric and congeneric characidae fishes in two tropical reservoirs. Iheringia: Série Zoologia, vol. 106, no. 0. http://dx.doi.org/10.1590/1678$4766 \mathrm{e} 2016012$.

MATO GROSSO. Secretaria de Estado de Planejamento e Coordenação Geral - SEPLAN, 2004. Zoneamento socioeconômico- ecológico do Estado de Mato Grosso: relatório técnico e projeto de lei. Cuiabá: SEPLAN/BIR D/PRODEAGRO.

MAZZONI, R., MARQUES, P.S., REZENDE, C.F. and IGLESIASRIOS, R., 2012. Niche enlargement as a consequence of co-existence: a case study. Brazilian Journal of Biology = Revista Brasileira de Biologia, vol. 72, no. 2, pp. 267-274. http://dx.doi.org/10.1590/ S1519-69842012000200006. PMid:22735133.

MCCAFFERTY, W.P., 1981. Aquatic entomology: the fishermen's and ecologists' illustrated guide to insects and their relatives. Boston: Jones \& Bartlett Learning, 228 p.

MELO, C.E.D., MACHADO, F.D.A. and PINTO-SILVA, V., 2004. Feeding habits of fish from a stream in the savanna of Central Brazil, Araguaia Basin. Neotropical Ichthyology, vol. 2, no. 1, pp. 37-44. http://dx.doi.org/10.1590/S1679-62252004000100006.

MOL, J.H., 1995. Ontogenetic diet shifts and diet overlap among three closely related neotropical armoured catfishes. Journal of Fish Biology, vol. 47, no. 5, pp. 788-807. http://dx.doi. org/10.1111/j.1095-8649.1995.tb06003.x.

MOLINIER, M., GUYOT, J.L., OLIVEIRA, E. and GUIMARÃES, V., 1996. Les regimes hydroiogiques de l'Amazone et de ses affluents. Paris: IAHS, pp. 209-222.

MUGNAI, R., NESSIMIAN, J.L. and BAPTISTA, D.F., 2010. Manual de identificação de macroinvertebrados aquáticos do Estado do Rio de Janeiro: para atividades técnicas, de ensino e treinamento em programas de avaliação da qualidade ecológica dos ecossistemas lóticos. Rio de Janeiro: Technical Books, $176 \mathrm{p}$.

NOGUEIRA, W.V. and COSTA, I.D., 2014. Aspectos da alimentação de Knodus heteresthes (Characiformes, Characidae) no igarapé do Nove, bacia do rio Machado, Rondônia, Brasil. Biotemas, vol. 27, no. 3, pp. 97-108. http://dx.doi.org/10.5007/21757925.2014v27n3p97.

NOVAKOWSKI, G.C., HAHN, N.S. and FUGI, R., 2008. Diet seasonality and food overlap of the fish assemblage in a pantanal pond. Neotropical Ichthyology, vol. 6, no. 4, pp. 567-576. http:// dx.doi.org/10.1590/S1679-62252008000400004.

ORTAZ, M., MARTÍN, R. and LÓPEZ-ORDAZ, A., 2011. Variación espacial y temporal en la composición de la dieta de peces invertívoros en un río neotropical, Venezuela. Revista de Biología Tropical, vol. 59, no. 3, pp. 1217-1231. PMid:22017127.

PIANKA, E. R., 1974. Niche overlap and diffuse competition. Proceedings of the National Academy of Sciences of the United States of America, vol. 71, no. 5, pp. 2141-2145. http://dx.doi. org/10.1073/pnas.71.5.2141. PMid:4525324.

PIANKA, E.R., 1973. The structure of lizard communities. Annual Review of Ecology and Systematics, vol. 4, no. 1, pp. 53-74. http:// dx.doi.org/10.1146/annurev.es.04.110173.000413.

REZENDE, C.F. and MAZZONI, R., 2003. Aspectos da alimentação de Bryconamericus microcephalus (Characiformes, Tetragonopterinae) no Córrego Andorinha, Ilha Grande - RJ. Biota Neotropica, vol. 3, no. 1, pp. 1-6. http://dx.doi.org/10.1590/ S1676-06032003000100012.

ROLDÁN, G., 1988. Guía para el estudio de los macroinvertebrados acuáticos del Departamento de Antioquia. Medellín: Universidad de Antioquia, Fondo FEN, 359 p.

ROSS, S.T., 1986. Resource partitioning in fish assemblages: a review of field studies. Copeia, vol. 2, no. 2, pp. 352-388. http:// dx.doi.org/10.2307/1444996.

SÁNCHEZ, R.M., GALVIS, G. and VICTORIANO, P.F., 2003. Relación entre características del tracto digestivo y los hábitos alimentarios de peces del río Yucao, sistema del río Meta 
(Colombia). Gayana, vol. 67, no. 1, pp. 75-86. http://dx.doi. org/10.4067/S0717-65382003000100010.

SANTOS, C.L., SANTOS, I.A. and SILVA, C.J., 2009. Ecologia trófica de peixes ocorrentes em bancos de macrófitas aquáticas na baia Caiçara, Pantanal Mato-Grossense. Revista Brasileira de Biociências, vol. 7, no. 4, pp. 473-476.

SCHNEIDER, M., AQUINO, P.P.U.D., SILVA, M.J.M. and FONSECA, C.P., 2011. Trophic structure of a fish community in Bananal stream subbasin in Brasília National Park, Cerrado biome (Brazilian Savanna), DF. Neotropical Ichthyology, vol. 9, no. 3, pp. 579-592. http://dx.doi.org/10.1590/S1679-62252011005000030.

SHIBATTA, O.A., 2006. Social behavior of pira-brasilia, Simpsonichthys boitonei Carvalho (Cyprinodontiformes, Rivulidae). Revista Brasileira de Zoologia, vol. 23, no. 2, pp. 375-380. http:// dx.doi.org/10.1590/S0101-81752006000200010.

SILVA, M.R.D. and HAHN, N.S., 2009. Influência da dieta sobre a abundância de Moenkhausia dichroura (Characiformes, Characidae) no reservatório de Manso, Estado de Mato Grosso. Iheringia: Série Zoologia, vol. 99, no. 3, pp. 324-328. http:// dx.doi.org/10.1590/S0073-47212009000300016.

SOARES, M.G.M., FREITAS, C.E.C. and OLIVEIRA, A.C.B., 2014. Assembleias de peixes associadas aos bancos de macrófitas aquáticas em lagos manejados da Amazônia Central, Amazonas, Brasil. Acta Amazonica, vol. 44, no. 1, pp. 143-152. http://dx.doi. org/10.1590/S0044-59672014000100014.
SPECZIÁR, A. and ERÖS, T., 2014. Dietary variability in fishes: the roles of taxonomic, spatial, temporal and ontogenetic factors. Hydrobiologia, vol. 724, no. 1, pp. 109-125. http://dx.doi. org/10.1007/s10750-013-1728-X.

TÓFOLI, R.M., HAHN, N.S., ALVES, G.H. and NOVAKOWSKI, G.C., 2010. Uso do alimento por duas espécies simpátricas de Moenkhausia (Characiformes, Characidae) em um riacho da Região Centro-Oeste do Brasil. Iheringia: Série Zoologia, vol. 100 , no. 3, pp. 201-206. http://dx.doi.org/10.1590/S007347212010000300003 .

VARI, R. P. and MALABARBA, L. R., 1998. Neotropical ichthyology: an overview. In: L.R. MALABARBA, R.E. REIS, R.P. VARI, Z.M.S. LUCENA and C.A.S. LUCENA, eds. Phylogeny and classification of neotropical fishes. Porto Alegre: EDIPUCRS, pp. 1-12.

VILELLA, F.S., BECKER, F.G. and HARTZ, S.M., 2002. Diet of Astyanax species (Teleostei, Characidae) in an Atlantic forest river in Southern Brazil. Brazilian Archives of Biology and Technology, vol. 45, no. 2, pp. 223-232. http://dx.doi.org/10.1590/ S1516-89132002000200015.

YASUAKI, T., TETSUYA, H. and JURO, Y., 1989. Scale regeneration of tilapia (Oreochromis niloticus) under various ambient and dietary calcium concentrations. Comparative Biochemistry and Physiology: Part A, Physiology, vol. 92, no. 4, pp. 605-608. http:// dx.doi.org/10.1016/0300-9629(89)90374-5. 